Article

\title{
Turnaround Management of Airport Service Providers Operating during COVID-19 Restrictions
}

\author{
Bassam Buhusayen *, Pi-Shen Seet (D) and Alan Coetzer (iD \\ School of Business and Law, Edith Cowan University, Joondalup, WA 6027, Australia; \\ p.seet@ecu.edu.au (P.-S.S.); a.coetzer@ecu.edu.au (A.C.) \\ * Correspondence: bassam_buhusayen@hotmail.com
}

Received: 9 November 2020; Accepted: 3 December 2020; Published: 4 December 2020

check for updates

\begin{abstract}
Many sectors worldwide have been impacted by government restrictions resulting from the COVID-19 pandemic. For example, restrictions on travel have resulted in major losses for organizations operating within the aviation sector. This study aims to emphasize the challenges faced by these organizations while they implement turnaround management strategies. The study is based on 30 semi-structured interviews with frontline managers working for airline service providers in three different departments of an airport in Australia. The organization has implemented several turnaround management strategies to survive the crisis caused by COVID-19 restrictions, creating new challenges for its work environment. Our findings indicate that the frontline managers faced two main challenges during and after the implementation of turnaround management strategies. First, inadequate human resources, caused by a lack of personnel resources and poor leadership selection. Second, a lack of communication, caused by excluding frontline managers from the turnaround management planning stage; poor sharing of information during the implementation stage; inadequate direction of frontline managers; and a lack of feedback channels regarding the change process. Based on its findings, the study recommends building a frontline manager task force and creating a strategic communication plan for frontline and senior managers.
\end{abstract}

Keywords: COVID-19; turnaround management; frontline managers

\section{Introduction}

The COVID-19 pandemic became a global health crisis soon after its inception in late 2019 [1]. Its rapid spread forced governments around the world to implement drastic restrictions to control the health crisis [2]. As a result, many industries have been negatively impacted, which has led to economic recessions for many countries around the world [3]. In addition, the unprecedented government lockdowns have caused severe financial losses for industries such as tourism and aviation [4]. In particular, the aviation industry-due to its high level of regulation and competition-is acutely sensitive to global events and crises, such as oil price fluctuations, terrorist attacks, volcanic eruptions, and fleet grounding. External events that cause flight cancellations and travel bans have direct impacts on the financial positions of the organizations operating within the aviation industry such as airlines, airport service providers, and airports [5]. Globally, the unprecedented COVID-19 crisis and resultant government lockdowns have severely impacted the vast majority of organizations operating within the aviation industry. For example, it is estimated that COVID-19 caused a drop of two-fifths of passenger traffic in 2020 [6]. The International Civil Aviation Organization (ICAO) estimated that airlines lost revenues totaling 112 to 135 billion USD in the first half of 2020 [7]. The drastic drop in air traffic brought operations within many organizations that provide services to airports to a complete stop.

To contain the spread of COVID-19, the Australian government introduced border closures for all inbound flights, with exemptions granted for cargo flights and passenger flights carrying Australian 
nationals or residents. Furthermore, the government also banned all outbound travel, with exemptions given to those who have an emergency and non-residents returning to their home country. The borders between the different Australian states were also closed, which negatively impacted the domestic air traffic. Some large organizations such as the national carrier Qantas, Virgin Australia, and many other organizations in the aviation sector were implementing radical change strategies to overcome the negative impact of COVID-19.

Financially troubled businesses aim to survive by searching for ways to increase their resilience and sustainability [8]. For example, transformational leaders tend make radical decisions related to the employment future of the employees that may include redundancies. However, such actions may cause dissatisfaction amongst remaining employees and those leaving, particularly when they are not involved in the change process [9]. This strategy is incorporated in "turnaround management", which has been defined as "the recovery of a firm's economic performance following an existence-threatening

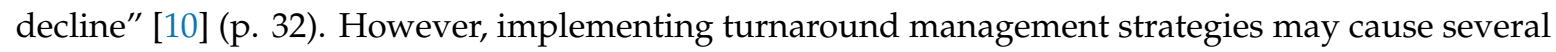
unprecedented challenges for organizations. For instance, although reducing staff numbers can form part of a turnaround management strategy, human resource experts are becoming increasingly concerned that when managers use staffing reduction simplistically-without consideration of alternatives-there are consequences for shifting greater responsibility onto remaining staff [11]. This may result in an extra cost of hiring new staff when the organization implements their turnaround strategy [12]. In particular, organizational behavior is negatively impacted through, for example, employees leaving and dissatisfaction among those remaining, particularly when they are not involved in the change process [13].

While the literature on turnaround and change management has generally identified some of the issues during the various stages of the process, such as failure to identify the cause of the organizational decline and/or too much focus on the retrenchment strategy, researchers' recommendations are mostly addressed to senior managers, while little attention has been given to frontline managers' roles in turnaround management [14-16]. Frontline managers are a crucial group because they are often required to implement the turnaround strategies designed by senior managers and have the most direct influence on operational staff attitudes, that is, they see the turnaround problem from both sides. In addition, the context of COVID-19 government restrictions has not been investigated. This study sheds light on the importance of the role of frontline managers in enabling the organization to achieve turnaround management objectives during a crisis by emphasizing critical skills, such as communication. Communication skills are the main pillars of human elements at the workplace, which encompass the innate skills, emotions, and culture of the employees [17]. Although the role of human elements is sometimes recognized in change management, in practice, these elements are neglected despite being the driving force to achieve organizational missions [18]. This study aims to develop a set of recommendations that practitioners can readily use to incorporate human elements, thereby improving turnaround management practices by easing the burden on employees during the COVID-19 crisis. This will help troubled organizations by highlighting critical elements overlooked by managers while reacting to the pandemic. So far, change management studies have not explicitly attempted to incorporate human elements, concentrating instead on general principles, such as budgeting, organizational structures, and marketing strategies [19-21].

This study aims to explore the challenges faced by organizations operating within the aviation sector in Australia while they implement turnaround management strategies in response to the COVID-19 crisis, from the perspective of frontline managers. Discovering and examining these challenges will help organizations execute turnaround management strategies more effectively and, therefore, increase the chances of their sustainability and resilience. Investigating the context of COVID-19 government restrictions is a novel contribution of this research, which will help organizations operating in the aviation industry to overcome the highlighted challenges prior to implementing turnaround management. This study also appears to be the first to investigate the challenges of frontline managers in turnaround management during the COVID-19 crisis. It also contributes to studies in aviation by 
highlighting the importance of preparing managers at all levels to more effectively respond to major shocks, so as to build resilience and sustainability in a sector that is heavily exposed to external shocks. This study is guided by the following question: What are the challenges of turnaround management strategies in the context of COVID-19 restrictions? To address this question, semi-structured interviews were conducted with 30 frontline managers who work in airport service providers in Australia and experienced turnaround management during the COVID-19 crisis.

\section{Background Material}

\subsection{Economies during the COVID-19 Crisis}

The COVID-19 pandemic resulted in lockdowns for many economies worldwide, which presented a unique challenge that existing change management literature has not documented. The unforeseen effects of the pandemic have spread fear, causing many experts to forecast a global recession [22]. According to Williams et al. [23], a crisis may negatively impact business workflow and disturb its daily operation. In addition, a crisis threatens organizational values and business models, which may lead to business distress [24]. According to Herbane [25], during an unanticipated crisis, a business is less resilient because of its lack of preparedness to manage the crisis' implications. Accordingly, the business is more dependent on government support and policy makers [26,27]. Nonetheless, turnaround management literature explains how to deal with an economic downturn from an organizational standpoint, as outlined in this section.

\subsection{Organizational Reaction to a Crisis: Theoretical Foundation}

There are a few definitions of turnaround management. For example, turnaround management is defined as the type of change management strategy that "seeks to create massive changes in an organization's structures, processes, culture, and orientation to its environment" [28] (p. 8). Nystrom and Starbuck [29] described turnaround management as a defensive strategy based on unsystematic reactions to corporate financial problems. Although turnaround management has several definitions, change management scholars tend to characterize the concept as having certain common elements [30,31]. They often characterize turnaround management as an ecological, holistic, and human-centered approach to transformation across an organization's structures, processes, and workflow that requires substantial modification of beliefs and norms while implementing radical organizational strategies.

Turnaround management may involve strategies that are related to any aspect of the organization, whether they are financial, administrative, market-related, human resource-related, or operational [32]. It is important to view change as something that not only directly influences systems, practices, and infrastructure, but also the human dimension, which is related to people management [20]. Amid the COVID-19 pandemic, the implementation of turnaround management strategies appears to be more challenging because people are less receptive to change and distracted by the severe change of lifestyle.

Turnaround management is a broad term that includes many strategies [32]. Boyne [33] found that most turnaround management strategies fall under three main categories: reorganization, repositioning, and retrenchment-the "3Rs" of turnaround management. Although the aim of these strategies is to yield better outcomes, they can negatively affect staff performance and organizational culture or climate indirectly as well as the success of the intended change [13]. In light of this significance, this study will limit its analysis to the three common strategies, in the context of COVID-19.

\subsubsection{Reorganization Strategy}

Reorganization, in a radical organizational change context, is typically a recovery process to survive a bankruptcy or financial challenge, with several goals affecting external or internal stakeholders [33]. According to Stace and Dunphy [34], reorganization could include a restructuring of assets and liabilities, 
changing of employee titles and roles, or changing of ownership through a merger or acquisition. Molinsky and Margolis [35] found that employees and managers experience significant disruption during the reorganization, including changing the nature of their roles within the organization and adding a heavier workload, which will negatively affect the work atmosphere.

\subsubsection{Repositioning Strategy}

Similar to reorganization, repositioning can strongly affect staff morale and productivity, for example, by resulting in new requirements for roles, hiring new staff, and retrenching existing personnel. Ryan et al. [36] suggested that strategic repositioning or reorientation is a response to declining market competitiveness. Managers may consider new models for adapting to changing market conditions [37], often revisiting an organization's core values [38]. Consequently, the shift in a company's vision may influence its dynamics, ultimately affecting the role of the frontline manager.

\subsubsection{Retrenchment Strategy}

Retrenchment strategies, such as downsizing, aim to align staffing costs to core business requirements so that a more efficient or effective human resource base can be created. Budros [39] (p. 326) defined downsizing as "an organization's conscious use of permanent personnel reductions in an attempt to improve its efficiency and effectiveness, noting that personnel reductions can be achieved through involuntary (layoffs) or voluntary (e.g., attrition and early retirements) means". While downsizing aims to improve an organization's economic wellbeing, scholars, such as Molinsky and Margolis [35], argue that managers often underestimate the effects of these strategies on employees and the organization's climate. In some cases, the employer perceives the employee as an expense, while the employee feels less secure and considers the employer a threat [40]. Some scholars have confirmed that downsizing has led to declining productivity and employee loyalty, as well as increased staff stress levels and turnover rates [41].

\subsection{Some Issues Created by Turnaround Management during a Crisis}

The turnaround management process usually involves five stages: (1) analysis of the situation, (2) creation of a plan, (3) turnaround implementation, (4) stabilization, and (5) return to growth [42]. When turnaround management practitioners or organizational managers use poor turnaround management practices during the process, several negative implications can arise. These ineffective practices are generated from the previously mentioned strategies and could arise at any stage of the process. The sections below discuss several poor turnaround management practices that existed before the era of COVID-19.

\subsection{Pressure for Quick Change}

Turnaround practitioners aim for quick change to save the organization's financial position [43]. Managers often pressure employees to absorb change quickly, without considering their involvement or response to it. Forcing employees to absorb change practices may sometimes be seen as intimidation or coercion [44]. The management team may face pressure as turnaround management strategies must be implemented alongside normal management activities. For example, legal issues concerning restructuring and layoffs sometimes prolong daily operations [45], causing the company's position to further decline [46]. While the appointed turnaround management practitioners, or new managers, tend to provide fresh perspectives and experience [47], they are sometimes perceived as outsiders who lack trust and credibility and have a hidden agenda in conflict with the employees' interests [48]. For these, and many similar reasons, quick transformational change often produces resistance in operational staff [44,49]. 


\subsection{Failure to Identify Problems}

Failure to identify the root of the organizational problems that initially caused the decline in performance can affect employees', customers', and suppliers' perception of transformational change [50]. Admitting problems can be challenging for the management team because it requires honest self-assessment. Many managers avoid admitting the consequences of their involvement to the detriment of the company's position. Staver [51] suggests that managers do not like to be held accountable for their own actions and tend to avoid taking responsibility when plans fail or performance drops, blaming their failure on others.

\subsection{Too Much Focus on Cost Cutting and Retrenchment}

While many organizations attempt to manage a financial crisis by reducing employee costs through retrenchment, some researchers suggest that successful businesses tend to concentrate on competing on quality rather than costs [52]. However, retrenchment often causes employees to resist change and place energy into self-protective activities and alliances. Instead of assisting with the turnaround strategy, employees with valued skills, irreplaceable experience, or strong qualifications tend to exit the organization first [49], depriving it of important knowledge and skills. An excessive focus on costs and retrenchment is a substantial trap for turnaround practitioners, with severe consequences for change effectiveness.

\subsection{Failure to Protect Internal Stakeholders' Interests}

Internal stakeholders' interests need to be protected. The turnaround management practitioner or manager needs to consider the interests of employees, internal auditors, support teams, and other managers when undertaking radical change activities. These staff may resist change if they feel their interests are threatened [53]. Underestimating an individual's readiness to change is a common problem [54]. Occasionally, turnaround practitioners and managers form strategies that protect some stakeholders but not others [55], leading to turnaround management failure, which emphasizes that all stakeholder interests need to be protected. For example, companies need to avoid making decisions that will protect managers but harm the floor employees. Every decision must be balanced and have sufficient rationale for it not to be perceived as biased [56].

\subsection{Lack of Communication}

Incomplete or misleading communication weakens leadership credibility during transformational change, causing workers to perceive a lack of trust, justice, and fairness, or, in some cases, to feel betrayed [57]. Sharing information with employees is important because it is critical for their planning, as well as those of their families. Employees make important decisions based on the news given to them. Regular and frequent communication during change helps to maintain trust and generates a positive spirit even when challenged with adverse results [58]. However, inconsistent and unclear communication is detrimental to turnaround management outcomes and will have a negative impact on the way employees perceive the process [59].

\subsection{Challenges for Frontline Managers}

Frontline managers play a major role in an organization. They strongly influence employees and are important to the success or failure of turnaround management, particularly in the context of a crisis, such as COVID-19. As such, it is surprising that they have received little attention in academic literature [60]. Specifically, existing scholarly guidance is lacking concerning the best approach to employ for directing frontline managers, especially in terms of the difficulties that they face with the increased administrative responsibilities [61].

A frontline manager's role is challenged by several obstacles, including the restriction of operational accountability, inconsistent decision-making authority (authority for specific everyday 
decisions rather than larger and more serious issues), disparity between strictly defined duties and technical work complications that are plagued with flexible demands, lack of participation in vital decision-making processes of the organization, and continuous duty conflicts that stem from the contradictory demands of workers and senior managers [62]. Martins [63] investigated the changing role of frontline managers over time and highlighted the inconsistencies that were found as the role changed, including the additional, and pragmatic, stress of supervision caused by such changes. This role change has been reflected in additional human resource duties or in the increased power in decision-making. However, Hales [62] found that frontline managers' focus has remained on work control, daily management, and problem-solving, while they have been continuously plagued with ambiguity and unclear accountability.

In recent decades, as the scope of the frontline manager role has expanded, the weight of the increased workload and more extensive duties has been compounded with other organizational failings [63]. Inadequacies in the definition of the position, and in the expectations that come with it, can result in role conflicts [60]. Poor support from management-which includes the direct manager of the frontline manager-surrounding managerial culture and systems and structures may further worsen role conflicts [63].

Studies have increasingly found that inadequate frontline manager training is a crucial contributing factor to certain negative outcomes; this was found to be a result of poor management, especially regarding the establishment of human resource management at the line level $[60,63]$. It is important to note that frontline managers lack essential support, despite being expected to manage many aspects on one front [62]. A shortage of adequate skills and expertise, inadequate training and assistance, substantial workloads, and conflicting priorities are other key issues that inhibit the ability of frontline managers to perform their people management duties appropriately $[64,65]$. Consequently, while there are obvious benefits to involving frontline managers in general management duties, their involvement might be subject to considerable restrictions. As Perry and Kulik [66] rather cynically asserted, allocating general management tasks to lower-level management may cause risks for the organization's biggest asset (employees) because those individuals may not be equipped or trained to handle such responsibilities.

This study will seek to accurately identify the key challenges that most frontline managers face during COVID-19 while implementing turnaround management strategies; from this, recommendations can be made to design better management systems. Some studies identify several key issues and challenges of turnaround management, while others identify some of the conflicting demands of the frontline manager role. By focusing on combining the above two scopes, this study presents new insights, by highlighting the challenges of frontline managers in the context of turnaround management. Furthermore, it emphasizes the role of strategic communication and accurate planning of human resources in enabling the organization to overcome some of the challenges created by COVID-19.

\section{Methodology}

\subsection{Research Design}

This study takes a qualitative approach, using semi-structured interviews to understand frontline managers' experiences with the turnaround management process during COVID-19. Qualitative methodologies can provide an in-depth understanding of social phenomena [67] and are more appropriate for exploratory research than quantitative methods, which confine responses to existing frameworks [68]. Qualitative research allows for a deeper study of individuals' experiences, perspectives, and contexts [69]. Emerging patterns can later be tested for generalizability with quantitative research.

Therefore, this study takes an exploratory approach focused on frontline managers' viewpoints. In doing so, the study fits in the interpretive paradigm [70]. Interpretive research aims at a deeper 
understanding of the nature and meaning of life experiences by examining a topic from the perspective of individuals' different experiences [71].

\subsection{Research Context}

Some global crises, such as sudden changes to oil prices, terrorist attacks, volcanic eruptions, and missing passenger flights negatively impact the aviation sector and force some organizations to implement turnaround management strategies to survive the financial implications. The COVID-19 pandemic has had a severe impact on the aviation sector worldwide, with many governments restricting or banning international travel to control the spread of the pandemic.

On 2 March 2018, the researchers gained approval from the University of Edith Cowan Human Research Ethics Committee to conduct 40 semi-structured interviews (approval letter-project No. 19514). Subsequently, the research was extended to conduct interviews under COVID-19 restrictions. Prior to conducting the interviews, the participants were given an information letter and consent form explaining the aim of the study. The interviews focused on three departments of the largest multinational organization operating within the aviation sector in Australia. Throughout its history, the organization has employed turnaround management using multiple change strategies, the latest of which was completed in June 2020 when the organization suffered financial losses because of the COVID-19 travel restrictions imposed on client airlines. According to an interview with the airport service provider terminal manager (26 June 2020), COVID-19 forced the organization to change its structure and leadership roles and impose significant budget cuts.

\subsection{Sample}

Turnaround management researchers often interview executives or senior managers to understand their experiences with declining divisions or companies [11,72]. Executives and senior managers are mainly involved in planning and directing the change process. By contrast, front-line managers and employees are directly involved in implementing plans devised by executives and senior managers and are thus likely to be better key informants about the study phenomenon. This study focuses on frontline managers, as they occupy the middle layer of the organizational structure and, therefore, experience firsthand both the goals of senior managers and employee responses.

For this study, 30 interviewees were selected from the organization's main operational departments: customer service, ramp, and baggage services.

The front-line manager participants occupy the middle layer of the organizational hierarchy, and their job titles include duty manager, supervisor, and team leader. Team leaders comprised $66.8 \%$ of the participants, $16.6 \%$ of the participants were supervisors, and $16.6 \%$ of the participants were duty managers. Table 1 summarizes the participants' positions within the organization.

Table 1. Summary of front-line manager participants' job titles.

\begin{tabular}{ccc}
\hline Position & Total Number of Participants & Percentage of the Total Sample \\
\hline Duty manager & 5 & $16.6 \%$ \\
\hline Supervisor & 5 & $16.6 \%$ \\
\hline Team leader & 20 & $66.8 \%$ \\
\hline
\end{tabular}

Table 2 summarizes the participants' demographic profiles. The participants' ages ranged from 15 to 63 years. The gender split was $63.3 \%$ female and $36.7 \%$ male. Regarding tenure, $40 \%$ of the participants have been with the company for over six years, which indicates that they have suitable experience in the subject field and, therefore, would have likely contributed positively to the results of the study. Regarding department split, $50 \%$ of the participants work in the customer service department, $30 \%$ in the ramp department, and $20 \%$ in the baggage service department. 
Table 2. Summary of participants' demographic profiles.

\begin{tabular}{|c|c|c|c|c|c|}
\hline Gender & $\begin{array}{l}\text { Total Number } \\
\text { of Participants }\end{array}$ & $\begin{array}{l}\text { Percentage of } \\
\text { the Total } \\
\text { Sample }\end{array}$ & $\begin{array}{l}\text { Working } \\
\text { Contract }\end{array}$ & $\begin{array}{l}\text { Total Number } \\
\text { of Participants }\end{array}$ & $\begin{array}{c}\text { Percentage of } \\
\text { the Total } \\
\text { Sample }\end{array}$ \\
\hline Male & 11 & $36.7 \%$ & Full time & 13 & $43.3 \%$ \\
\hline Female & 19 & $63.3 \%$ & Part time & 17 & $56.7 \%$ \\
\hline Department & $\begin{array}{l}\text { Total number } \\
\text { of participants }\end{array}$ & $\begin{array}{l}\text { Percentage of } \\
\text { the total sample }\end{array}$ & & & \\
\hline $\begin{array}{c}\text { Customer } \\
\text { service }\end{array}$ & 15 & $50 \%$ & \multirow{3}{*}{$\begin{array}{c}\text { Years of } \\
\text { experience with } \\
\text { the company }\end{array}$} & \multirow{3}{*}{$\begin{array}{c}\text { Total number of } \\
\text { participants }\end{array}$} & \multirow{3}{*}{$\begin{array}{l}\text { Percentage of } \\
\text { the total sample }\end{array}$} \\
\hline Ramp & 9 & $30 \%$ & & & \\
\hline \multirow[t]{5}{*}{$\begin{array}{l}\text { Baggage } \\
\text { services }\end{array}$} & 6 & $20 \%$ & & & \\
\hline & & & 0-1 year & 1 & $3.3 \%$ \\
\hline & & & $1-3$ years & 11 & $36.7 \%$ \\
\hline & & & $4-6$ years & 6 & $20 \%$ \\
\hline & & & $\begin{array}{l}\text { More than } \\
6 \text { years }\end{array}$ & 12 & $40 \%$ \\
\hline
\end{tabular}

\subsection{Research Analysis}

Thematic analysis was used to analyze the data to identify patterns or themes that displayed commonalities, relationships, overarching patterns, or theoretical constructs [73]. Six major steps were followed in accordance with Braun and Clarke's [73] thematic analysis method. First, the researchers transcribed the interviews using a professional transcriber. The researchers reread the transcripts several times and captured important notes. Second, the researchers mapped out the notes and categorized the important information. The researchers uploaded the transcripts into NVivo and started coding the important information. Thereafter, the researchers categorized and segregated the information under each code. Third, the researchers collated the data under potential themes. Fourth, the researchers reviewed the potential themes by mapping out and downsizing the information, only retaining the relevant information. Fifth, the researchers identified and highlighted common patterns and themes. Accordingly, the researchers merged the sub-themes, revised the themes, then finalized the selected themes. Sixth, the researchers produced the final analysis report with examples and quotes under each theme.

\subsection{Mapping out Important Information and Coding}

In qualitative methods, coding is the first step of a systematic approach to prepare and order the data for analysis and reporting. According to Saldaña [74], a code is a term or short phrase that assigns an attribute to a segment of language-based data. The researchers employed two coding methods-structural and pattern coding - that were used across three cycles to identify and classify common themes. Before sorting and classifying the data under each code, the researchers highlighted the relevant and important data based on the notes taken during the reading of the transcripts. Accordingly, the researchers attempted to identify categories and classifications.

According to Elg and Ghauri [75], NVivo software is the most used software for categorizing and organizing data in qualitative studies. NVivo enabled the researchers to store the data, organize and sort the data into coding, and perform the thematic process. Accordingly, NVivo was used to manually code each participant's transcribed interview [75]. The first and second cycle of the coding process was based on a structural coding technique that categorizes data based on interview questions' headings and subheadings. Conversely, the third cycle of coding is based on a pattern coding technique 
that identifies similar data, then groups them together to generate themes for answering the study's questions [76]. Overall, the researchers identified a pool of 34 cycle codes.

\subsection{Reduction and Elimination}

To ensure an accurate representation and understanding of the topic, the coded data were reviewed after the NVivo coding process. The researchers reviewed the textual data to ensure that the identified themes were explicitly stated by the interviewees. The elimination of information was based on its importance, and the importance of the information was based on the quality of the content and the number of times that participants mentioned this information. The identified themes were assessed to ensure that each critical moment/event or lived experience was essential for understanding the study's questions.

\subsection{Searching, Reviewing, and Identification of Themes}

Ritchie and Lewis [77] believe that the frequency of theme occurrences does not necessarily signify that the theme is important for answering the study's questions. The invariant constituents of the experiences were clustered to form thematic labels. Based on the invariant pattern constituents, specific themes emerged from the thematic labels. The preliminary grouping code report was used to generate the main thematic labels that were important to the primary and secondary research questions. After sorting the data into the first, second, and third cycle codes, the researchers used the pattern coding technique to identify thematic and conceptual similarities.

After transcribing, coding, and sorting the data, the researchers began searching for sub-themes by collating codes into potential themes. Sub-themes were reviewed numerous times and then merged into two meaningful themes.

\section{Findings}

This study focused on the lessons learned from the mistakes and challenges that arose during the implementation of turnaround management strategies during COVID-19. The findings indicate that two main themes are related to turnaround management implementation. Each theme comprises of several sub-themes. The sections below present our findings using the "power" and "proof" quotes technique [78]. According to Pratt [79] (p. 501):

Power quotes are those in which the informant is so concise, or insightful, that the author could not do a better job of making the same point. These appear in the main text of the study. Proof quotes are often used to show the prevalence of a point. These quotes may be a source of triangulation, in which I show how each data source supports a particular argument. Proof quotes may also be presented as a bundle of short quotes that are used to illustrate the prevalence of findings.

This study has followed Pratt's [78] suggestion to place the power quotes in the body of the paper and the support quotes in tables. The power quotes are the most compelling data and effectively illustrate the researcher's ideas, while the additional data in the table - the proof quotes-aim to illustrate a particular idea or argument. This also means that the researcher may have several proof quotes in one table to reflect each idea [78].

\subsection{Theme One: Inadequate Human Resources}

"Inadequate human resources" was established as theme one after merging two sub-themes: lack of personnel resources and poor leadership.

\subsubsection{Lack of Personnel Resources}

Based on the responses of 13 interviewees, a shortage of operational personnel was one of their greatest challenges. The shortage of personnel resources was mainly caused by a lack of planning for 
staffing, especially for the company cargo operation, as it handled more cargo flights than anticipated because of a reduction in passenger flights. The senior managers created a resource plan for the turnaround management strategies to ensure that subsequent operations performed at the required standards. However, during the downsizing process, it was difficult for senior managers to accurately determine who should be made redundant and who should be retained. According to the participants, the deficiencies in resource planning were caused by a lack of consultation with the frontline managers, who could have offered valuable insights regarding resource planning due to their intimate knowledge of the organization's operational activities. Additionally, the deterioration in employee morale contributed to an increase in the number of people taking sick leave, while employees who anticipated losing their jobs used their accumulated sick leave. For example, one participant stated:

I think that some of the staff were calling in sick and were not wanting to come to work because they were worried that they will get sick because of COVID and also because the government was paying them while they sit at home and do nothing. They wanted to take as much sick leave as they could before they were made redundant. If the duty managers were to get a flight that was down because of someone sick and rang someone in that group, they would be less likely to come in. It would be the same as the disruption. They wouldn't want to help because they felt like they were getting lazy and rather get the money without having to work.

Some senior managers claimed that they were not given a choice and had to adhere to the executive managers' decisions regarding staffing numbers. Therefore, a lack of personnel resources was a challenge that frontline managers had to manage. In addition, a lack of experienced leadership compounded the difficulties for the frontline managers.

\subsubsection{Poor Leadership Selection}

The participants highlighted that although there was a lack of resources and experience in dealing with the constantly changing variables of COVID-19, inept new leaders were appointed from within and outside the organization. Ten interviewees mentioned that the approach and style of the newly appointed external leaders were not suitable for the current environment. The new leaders came from different aviation backgrounds and experience, and some had limited rapport with the employees. In addition, some were aggressive and forceful toward the employees, and were unable to gain their support. The frontline managers found it difficult to work with the newly appointed external leaders and challenging to justify the new leaders' behavior to the employees. In contrast, some of the internally appointed leaders exhibited a positive attitude; however, they lacked the required situational experience and, therefore, needed the frontline managers' support to complete the required jobs. For example, one participant stated:

There is inconsistency, so you'll find the ones that were experienced; they were able to handle the issue instantly, I remember. At one point, there was a major delay with an Air X flight and an experienced frontline manager instantly knew what to do. However, the one that had just finished this shift prior was stressed about not knowing what steps should be taken next. As soon as he started, a more experienced frontline manager instantly knew what steps needed to be taken. Again, it comes down to experience and trust between the more experienced frontline managers and certain employees. There was an instant understanding that we were in a difficult situation and that the employees would help.

Poor decisions regarding the selection of staff for leadership roles were apparent to the employees and clients' airlines, and the frontline managers had to persevere through the negative consequences. However, some senior managers believed that the new leadership appointees were suitable to handle the implications of COVID-19 and that they needed time to develop and settle in their roles. Therefore, although some participants believed otherwise, poor strategic decisions were another challenge that frontline managers had to face (Table 3). 
Table 3. Inadequate resources.

\begin{tabular}{|c|c|}
\hline Category & Proof Quote \\
\hline $\begin{array}{l}\text { Lack of personnel resources: } \\
13 \text { comments }\end{array}$ & $\begin{array}{l}\text { Participant stated: "Many supervisors and duty managers struggled with } \\
\text { having a lack of staff. The staff were calling in sick and we didn't know how } \\
\text { to handle the tough situations". } \\
\text { Participant stated: "You try and cover, and get the best that you can. As I've } \\
\text { mentioned, some staff will call sick, and will try and take advantage of the } \\
\text { fact that they know they're leaving, and that they've found something else. } \\
\text { Certainly, sick leave, you can't take with you. People are feeling that it's } \\
\text { their right to take it". }\end{array}$ \\
\hline $\begin{array}{l}\text { Poor leadership selection: } \\
10 \text { comments }\end{array}$ & $\begin{array}{l}\text { Participant stated: "Some managers buckled. They didn't take it too well, } \\
\text { while some managers excelled. The ones that excelled have the experience } \\
\text { and good management skills. It's nothing new to them. Change is always } \\
\text { going to happen and they're trying it themselves personally. When you go } \\
\text { and talk to them, they're very confident. They tell you that it's nothing new, } \\
\text { that things are always changing and that you must adapt. They put you at } \\
\text { ease. Some of them don't take it too well because of the lack of experience } \\
\text { and management skills, but I don't think they were appointed at the } \\
\text { right time". } \\
\text { Participant stated: "Just like when I was appointed team leader and then } \\
\text { there was another team leader on. I was getting quite confident in my } \\
\text { position, obviously, as you do. I don't need to go to them for help anymore; } \\
\text { I can solve the issues for myself. I have like a special code that allows me to } \\
\text { do these things rather than annoying that said person in charge. I will fix } \\
\text { the issues myself using my own code, which was fine. One time, a mistake } \\
\text { was made. I got blamed for it, but it wasn't even my fault; it was their fault. } \\
\text { Everyone started to blame management for giving me the job, saying that I } \\
\text { was too new for it. That really upset me and dropped my confidence". }\end{array}$ \\
\hline
\end{tabular}

In addition to inadequate human resources, a lack of communication during the turnaround management process also challenged frontline managers, inadequately directing frontline managers to achieve turnaround management objectives.

\subsection{Theme Two: Lack of Communication}

"Lack of communication" was established as theme two after merging four sub-themes: excluding frontline managers from the turnaround management planning stage, insufficient sharing of turnaround management information during the implementation stage, inadequately directing frontline managers to achieve turnaround management objectives, and lack of feedback channels.

\subsubsection{Excluding Frontline Managers from the Turnaround Management Planning Stage}

The interviews highlighted a previously concealed issue between frontline managers and senior managers, in which frontline managers felt excluded from senior managers' actions during the turnaround management planning stage. Nine interviewees believed that, during the turnaround management planning stage, frontline managers were disappointed because senior managers did not consult, include, or involve them in the turnaround management plan and its potential effects. The interviewees highlighted that the turnaround management practices were planned by non-operational, back-office employees who had limited experience in the operation of ground handling. They also believed that the senior managers' experience with frontline operations was lacking because they did not spend enough time in operations as they mostly focused on administrative tasks. Consequently, there was limited consideration for the pre-existing dynamic and norms of the employees during turnaround management planning. Avoiding, bypassing, and isolating frontline managers evoked a feeling of disappointment, particularly because frontline managers were expected to 
facilitate turnaround management practices regardless of their views of the plans and implementation thereof. For example, one participant stated:

The frontline managers probably expected that they would be consulted during the planning stage of the transformation. However, what's happened locally is that a certain department or a certain person would make the decisions, make all the calculations, do all the math, present that to the senior management, and then it'll get approved immediately, with no communication. We get bypassed every single day.

Some senior managers claimed that they followed the executive managers' orders by keeping the turnaround plan confidential. Therefore, the frontline managers were not consulted during the turnaround management planning stage; this lack of communication created a sense of isolation.

\subsubsection{Insufficient Sharing of Turnaround Management Information during the Implementation Stage}

Based on the responses of 16 interviewees, it was apparent to the employees that a gap existed between the frontline managers and senior managers in terms of sharing information while implementing turnaround management strategies. As the senior managers communicated information to the frontline managers poorly, distrust began to develop between the two parties, which negatively affected their relationship. The frontline managers did not receive sufficient information to share with the employees; therefore, the employees had many unanswered questions. The employees expected the frontline managers to deliver such information, particularly if it was basic, non-confidential information. The lack of communication embarrassed the frontline managers during conversations with the employees regarding the turnaround management practices. Although restructuring the frontline managers' unit was part of the retrenchment process, the frontline was still expected to facilitate turnaround management practices and achieve the required outcomes. The employees approached the frontline managers for information, but the frontline managers could only provide limited answers because they were neither involved, nor informed. The lack of communication between senior and frontline managers negatively influenced the employees' perception of the organization and its turnaround management plans because employees sensed that the frontline managers were anxious and doubted the effectiveness of those plans. Therefore, the negative climate was more apparent during the turnaround management process, especially in the study's context, as people had to experience the negative impact of a lockdown. For example, one participant stated:

You can feel the lack of communication between the upper tiers and the middle tiers, in the sense that they wouldn't tell you what's happening. If you go and ask the frontline managers, they will have no idea what the development was. They themselves would be informed at a later time of all the things that are happening.

Not sharing important information about the turnaround management practices prompted many questions, which were not answered. In addition, the inadequate direction that was given to the frontline managers on how to achieve turnaround management objectives caused confusion and doubt regarding the reliability of the turnaround management plan.

\subsubsection{Inadequately Directing Frontline Managers to Achieve Turnaround Management Objectives}

From the perspective of eight interviewees, the senior managers did not provide the frontline managers with a clear direction on how to achieve the turnaround management objectives. This caused the frontline management to feel they were independent and without adequate support, particularly when they were working in uncertain and changing circumstances. The frontline managers were pressured to accomplish the turnaround plan; however, they were unclear about the practical steps required to accomplish it. This resulted in feelings of hatred and anger toward the senior managers because they used their higher status to rise above the frontline managers instead of supporting them. As a result, some of the frontline managers resisted some turnaround management activities, although this form of resistance was unapparent. For example, one participant stated: 
At some point, I felt that there is no point in talking to them. I felt that I have been betrayed. I do feel betrayed and there was a point where I didn't even want to talk to them. They are not telling me anything; they do not even know what they want to achieve. I don't want to talk to anyone who is more senior than me or who is on a higher level than me.

The consequence of inadequately directing the frontline managers during the turnaround management process was that they were left to handle the situation with only their personal efforts. Although some senior managers claimed that the overall direction, which starts from the executive managers, was also inadequate, they were reluctant to move forward without referring back to the executive managers. As noted above, the organization's bureaucratic system negatively influenced the change process because many turnaround management practices were adopted without questioning their effectiveness. Several practices were largely ineffective and did not suit the local port environment or fulfill the needs of the operation during the pandemic. The frontline managers assumed the responsibility for overcoming these challenges, and this was exacerbated by the lack of feedback channels.

\subsubsection{Lack of Feedback Channels}

Eleven interviewees asserted that the frontline and senior managers provided opportunities for frontline managers to share their feedback about the implementation of the turnaround management strategies. However, sharing feedback and gaining frontline managers' input is an approach that could have been used to reduce tension, which may have positively influenced the relationships between the frontline and senior managers. Sharing feedback may have encouraged an open channel of communication between the two parties, from which a basis for a relationship could have been established. However, the inability of frontline managers to share their thoughts evoked feelings of disappointment. For example, one participant stated:

It would be good to have some input and have some questions thrown at us so we could have some input, but I don't think that happened, in all honesty. It'd be good to throw out some ideas, but I don't think that we would be involved on a day-to-day basis in making decisions.

Table 4 displays the findings mentioned above and provides proof quotes to support the power quotes provided in this section.

Table 4. Lack of communication.

\begin{tabular}{ll}
\hline \multicolumn{1}{c}{ Category } & \multicolumn{1}{c}{ Proof Quote } \\
\hline $\begin{array}{l}\text { Excluding frontline managers from the turnaround } \\
\text { management planning stage: } 9 \text { comments }\end{array}$ & $\begin{array}{l}\text { Participant stated: "I definitely think sometimes that } \\
\text { they would bypass some people. If they (senior } \\
\text { managers) get on well with the person, then they will } \\
\text { exchange a lot with them, no matter the status in the } \\
\text { company. I do feel that this is not the correct way to } \\
\text { go with information sharing in a company, especially }\end{array}$ \\
$\begin{array}{l}\text { in the face of transformation like that". } \\
\text { Participant stated: "All of the decisions are more or } \\
\text { less out of our hands. We don't get to really make any } \\
\text { drastic decisions. We were not involved in } \\
\text { any planning". }\end{array}$ \\
\hline
\end{tabular}


Table 4. Cont.

\begin{tabular}{|c|c|}
\hline Category & Proof Quote \\
\hline $\begin{array}{l}\text { Insufficient sharing of turnaround management } \\
\text { information during the implementation stage: } \\
16 \text { comments }\end{array}$ & $\begin{array}{l}\text { Participant stated: "I think that morale absolutely } \\
\text { went down. We were right down there for a while. } \\
\text { No-one was happy coming to work when you feel } \\
\text { like you've been left in the dark, when things are } \\
\text { changing, and when you are not being told all the } \\
\text { information. It lessens morale, starts you not wanting } \\
\text { to be there, and makes it an unhappy workplace. } \\
\text { During the change, I just felt the same as everyone } \\
\text { else: that we could have been given more information. } \\
\text { Even if there was nothing new that they knew, } \\
\text { just come to us as a group and let us know: } \\
\text { 'Unfortunately, we have no updates today and we } \\
\text { don't know anything new. As soon as we do know } \\
\text { something, we'll let you know.' Just to keep us in } \\
\text { number-I don't think I lost respect, but I think that I } \\
\text { did wonder if they cared at all about the people who } \\
\text { work under them losing their jobs". } \\
\text { Participant: "It was insufficient. The information they } \\
\text { were giving to us wasn't confirming anything we } \\
\text { wanted to know. They were always quiet about it. } \\
\text { We only find out after things are implemented". }\end{array}$ \\
\hline
\end{tabular}

Inadequately directing frontline managers to achieve Participant stated: "You didn't feel that you got turnaround management objectives: 8 comments anything from them during that time. You've given your hard work at that time, but during the transformation, when you wanted that sort of direction, you didn't receive that sort of information to help you to accomplish the job".

Participant stated: "Most of the instructions we received were vague; this doesn't help. I feel a lot of things were not thought of. The plan looked good on paper. When it comes to implementing it, it was left to us to sort it out and each duty manager will act differently on the day ... some will be able to go through the shift safely and do well and some not, but who's to blame?"

Lack of feedback channels: 11 comments Participant stated: "If you enhance your communication and your messages from the top, you work your way through, and it will actually work vice versa as well. If I communicate with you today about the issue, I'll just say: 'Sam, today is such and such as such.' Okay, next day, you come back to me and you can also communicate back to me or you can give me your opinion on it. I could probably learn from that as well, but management didn't allow any room for feedback ... sadly!"

Participant stated: "From my knowledge, a lot of information was fed back to senior management, but little or no action was taken, and neither was a response given back. It was a problem because we didn't know who we should speak with and ensure that things are done and feedback is taken into consideration; there wasn't a direction of who we should give our feedback to".

There were many challenges caused by the lack of communication during the turnaround management process, and the frontline managers had to deal with the outcomes. 


\section{Discussion}

\subsection{First Theme: Inadequate Human Resources}

One of the major issues during the turnaround management process was inadequate personnel resources, while isolating frontline managers from the planning stage and ignoring their views regarding adequate resource levels contributed to escalating the problem. There was a major division between frontline and senior managers, which contributed to low morale among employees. This can be explained by Armstrong-Stassen [80], who discussed the reason behind employees' negative reactions to change. The study indicated that frontline managers are negatively affected by downsizing because they experience an increase in their workload as a result of the turnaround management strategy. Due to the division between frontline and senior managers-where there was an apparent lack of support and direction for the frontline managers-some frontline managers discreetly resisted the turnaround management strategies, as stated in an earlier section. While resistance among operational staff is well documented in change management research [81-84], it can also include the frontline managers in some cases [48].

The findings suggest that the consequences of failing to consider human elements included poor planning and management of the turnaround management process, which added to the morale and productivity problems. For example, there was a failure to consider the long-term effect of redundancies on employees' skill sets and experiences, as well as other resources that were required to run the organization. In line with this finding, Jacobs et al. [85] explained that turnaround management practitioners tended to aim for a quick change to save the organization's financial position, often overlooking the subsequent effects on staffing and other resources. In this study, emphasis on a quick change was apparent to the interviewees; it resulted in a major questioning of managerial decisions and the change process in general. Resource planning did not account for the deterioration in employee morale, which contributed to an increase in sick leave.

The findings highlighted the importance of involving frontline managers in operational decisions because they have adequate skill sets and knowledge to improve the process. These results are in line with those of Townsend and Russell [86], who believe that the management of individuals should be more integrated, as well as shared with frontline managers, instead of being the exclusive task of a few specialist managers. Furthermore, the findings are aligned with the literature that suggests the importance of involving frontline managers in decision-making pertaining to people management $[65,87,88]$. Frontline managers are appropriately positioned to handle challenges such as resource planning as they are the closest to floor workers, interact with them regularly, and are directly responsible for the daily management of the workforce.

\subsection{Second Theme: Lack of Communication}

The early stages of the turnaround management process involve preparing employees for change by consistently and clearly communicating the need for change-as well as the details of the change process-and involving or consulting employees as much as possible $[60,86]$. The literature suggests that such preliminary practices are strongly related to the success of turnaround management [89]. In corroboration with the existing literature, the researchers consistently found that a lack of communication caused employees to develop negative emotions toward the turnaround management strategies, which subsequently influenced their social exchange in the workplace.

In this study, the lack of communication during the turnaround management process caused resistance; frontline managers and employees felt that they were not involved in the change process and that the change was imposed too suddenly and quickly. This result matched that of Caldwell [44], which demonstrated that pressuring employees to absorb change too quickly, and without consideration of their need for communication regarding the required changes and redundancies, could be perceived as intimidation, which leads to resistance. In this study, the turnaround management strategies involved creating a new organizational structure, changing the leadership personnel, redefining staff 
duties, combining positions, reducing full-time staffing, and building a new climate that is focused on better staff productivity and morale. However, the findings indicate that employees did not receive the change well because too little information was provided about the turnaround management strategies and its effects on employees. In line with this finding, Lewis [90] emphasized that organizational information must be unambiguous and disclosed as needed, whether favorable or unfavorable.

The results corroborated the notion that the role of communication is associated with improving staff attitudes and behavior during turnaround management. In addition, this study's findings are also consistent with those of other studies that found communication to be a critical element of human resource practice during a change process [90]. A communication plan can help clarify the change objectives, engage employees, help their psychological adaptation during radical change, reduce rumors, and build trust between managers and employees. In addition, although all managers should be involved in communication to deliver a consistent message, it is important to select the right managers to communicate key messages.

Existing studies suggest that misleading, or a lack of, communication during times of change is likely to cause resistance to change, low morale, and a change in the social exchange dynamics in the workplace [57-59,90]. This study suggests that senior managers use a collective approach for announcing news, rather than an individual or uncoordinated one. A collective approach involves coordinating communication across teams and creating a cohesive unit that focuses on essential goals, as well as minimizing social problems (such as an "us and them" mentality), poor relations between the management team and employees, the conflict between individuals or groups, politics, low morale, and resistance.

This study found that frontline managers had little involvement in the change process; they merely received limited information and were asked to develop training processes and upskill new staff. Therefore, they perceived that they were pushed aside and that their attempts to communicate with some of their staff did not improve their wellbeing. When comparing these results to previous studies, it must be pointed out that the value of engaging employees and lower-level managers during change processes is well documented [91-93]. However, limited studies have identified how to effectively mobilize frontline manager contributions to improve turnaround management [94]. Barrett [17] created the "Strategic Employees Communication Model" to help organizations that are undertaking radical change to communicate effectively and gain better outcomes. Accordingly, Barrett [17] highlighted the importance of involving middle and senior managers to lead the communication plan. However, the analysis in this study is vital in enabling new conclusions to be drawn about the role of frontline managers and their contributions to the strategic communication of turnaround management strategies amid COVID-19 restrictions.

\subsection{First Theoretical Contribution: Deeper Understanding of Frontline Managers' Challenges during Turnaround Management}

This study contributes to an understanding of the role demands, expectations, and challenges that frontline managers face during turnaround management in the context of a severe crisis, such as the COVID-19 pandemic. While several studies have highlighted the increasingly conflicting duties of frontline managers, this study's contribution is a continuation of that of McConville and Holden [95]. McConville and Holden [95] described frontline managers as being "piggy in the middle, caught between the directives of their seniors and the difficulties of the service on the one hand, and the demands and problems of their staff and consumers of the service on the other" (p. 421). This conflicting demand that frontline managers face is severe, particularly in the context of COVID-19, in which the work environment is rapidly changing. In the aviation industry, and particularly in the airport service provider business, frontline managers must strike a balance between senior management, employees, and client needs. Senior management expects cost cutting and a reduction in labor hours, while the client airlines expect a high-end service. However, employees expect not to work excessively, so they can avoid being infected by COVID-19. Additionally, this study contributes to 
turnaround management research by revealing the challenges frontline managers face during the planning and implementation stages of turnaround management. Some turnaround management studies stress the negative impacts of poor communication on leadership credibility during turnaround management, which often causes employees to experience a lack of trust, justice, or betrayal $[57,96]$. Poor management communication thus affects morale and creates confusion and ambiguity among the employees [97]. However, this study casts new light on this issue by investigating the perspectives of the frontline managers.

\subsection{Second Theoretical Contribution: Improving the Understanding of the Frontline Manager Role}

Existing literature has covered the role of the frontline manager, but little attention has been paid to the context of turnaround management. Although several studies cover the frontline manager role, they mainly focus on functional tasks; they do not analyze the role within the context of a crisis, such as COVID-19 $[60,63,98]$. This study is unique in seeking to understand the role of frontline managers in facilitating turnaround management while being challenged by COVID-19 restrictions.

Kerr et al. [99] summarized the frontline manager role as follows: scheduling, planning, and allocating work; monitoring work conduct and output; inspecting equipment, cleanliness, and safety; directing the establishment of new equipment; handling unforeseen issues with recruitment, production, and equipment; enforcing discipline; managing conflicts; counseling; training; keeping records; and helping in work operations. According to Thurley and Wirdenius [100], the essential roles of supervision include ensuring the continuity of production and achieving operational reality with written plans [101].

While the above duties are typical of a frontline manager's role, the role amid a crisis has not been discussed in detail. This study presents turnaround management strategies as an analytical framework, as well as a new contribution to knowledge, as mentioned in an earlier section. Accordingly, we tailored a new list of frontline manager duties, which are primarily concerned with viewing the role of frontline managers during the COVID-19 restrictions in the aviation sector. It includes the following:

1. Sharing information and raising awareness of COVID-19 through informal channels with employees.

2. Providing social support to fellow frontline managers and employees.

3. Enhancing employees' performance by motivating and boosting their morale.

4. Managing employees' workloads and ensuring they are safe by following the government restrictions and safety procedures.

5. Using social exchange to facilitate turnaround management practices.

6. Improving resources using the frontline managers' experiences.

\subsection{Practical Contribution}

This study developed a set of recommendations for improving turnaround management practices while facing COVID-19 restrictions to ease the burden on employees. It highlighted that turnaround management in the context of COVID-19 restrictions has several negative practices related to people management, which affect the role of frontline management, workflow, and the psychological wellbeing of both employees who leave and those who remain. In the following two sections, the researchers suggest two recommendations that will improve turnaround management practices and reduce the negative effects on employees. Regardless, it is important to note that some of these suggestions are specifically related to frontline managers, while others are related to other key actors, such as employees and senior managers.

The study's findings also have practical implications for improving sustainability and resilience among firms in the aviation sector. While turnaround management includes repositioning strategies that involve future investments [36,37], it is important to note that there is an interdependence between COVID-19 and turnaround management when dealing with investment planning. The negative 
impacts of a crisis such as COVID-19 on air traffic may force organizations operating in the aviation sector to re-evaluate their investment strategies by implementing short- and medium-term investment projects, rather than long-term projects to avoid over investment and higher risks. Research by Birolini et al. [102] highlighted the importance of considerations relating to service quality and price sensitivity for passengers. Turnaround management strategies during/after COVID-19 may need to factor in the possibility that passengers may prefer greater attention to safety measures within airports, rather than price or service quality issues.

\subsubsection{Build a Frontline Manager Task Force}

The findings show that inadequate human resources were a critical issue during turnaround management. Therefore, it is suggested to form a task force team to address this issue.

A lack of foresight regarding resources leads to a drop in service levels. As a result, frontline managers will face the difficult prospect of managing clients' expectations. This lack of foresight will cause employees to negatively perceive the quality of planning, communication, and decision-making, which affects their attitudes toward the change.

Excluding frontline managers with expertise in human resources generates negative impacts on the change process. Therefore, the group steering the change process needs to consult widely, referring to subject matter experts, gathering information, and evaluating progress toward goals.

A special frontline manager task force should be formed, with the specific aim of facilitating turnaround management practices and ensuring that the objectives are being accomplished. The task force should consist of highly skilled individuals who represent all departments and aspects of the organization. It should also involve individuals who understand the details of each job, the required skill sets, and the required training during turnaround management, who are able to manage clients' expectations, and who are able to motivate and influence employees to maintain effective interpersonal relationships in times of turbulence, stress, and uncertainty. The frontline manager task force should be able to provide notable input while establishing a strategic human resource management plan that incorporates the needs of staff at all levels and areas. The plan may also encompass multiple scenarios and response options, as well as training schedules and procedures for redesigning new roles for staff.

\subsubsection{Create a Strategic Communication Plan for Frontline and Senior Managers}

The findings show that the lack of communication was perhaps the biggest challenge while implementing turnaround management in the context of COVID-19. Therefore, it is suggested to create a joint communication plan between senior and frontline managers.

This study highlighted that frontline managers are a critical asset during turnaround management. Frontline managers are at the heart of the change, and their "buy-in" is fundamental to its success. Frontline managers greatly influence operational employees; they lead the vast majority of the workforce and have direct contact with employees on a daily basis. During turnaround management, frontline managers should be tasked with delivering critical messages from senior managers to employees and with helping them to sell important ideas. Frontline managers must work on delivering employees' feedback to senior managers and engaging employees in the turnaround management process. Additionally, as frontline managers work closely with clients, they can provide positive messages to them regarding the change process. Frontline managers must have an active role in identifying problems and helping senior managers rectify them. This is because their role in communication is critical一they understand the operations, can identify the gaps, strengths, and weaknesses, and have hands-on experience, which qualifies them to make critical input in every stage of turnaround management.

Planned communication is vital for turnaround management success. Senior and frontline managers should not communicate outside the plan, as this can confuse and agitate staff. The communication plan should indicate what key messages should go to which groups in the organization and how and when they should be delivered. This includes communication goals, strategies, and channels; it could also include scenario analyses so that the right message is delivered 
if the variables change. Additionally, it can consist of a hotline number or email that employees can contact when they need to verify any information. It can also include a frequently asked questions list that can be distributed to frontline managers so that they can communicate the right information when they are onsite. Human resource personnel and frontline managers should play an important role in creating the plan.

\subsection{Limitations and Future Research}

This study has revealed the importance of gaining buy-in from frontline managers when undertaking turnaround management in the context of a severe crisis, such as COVID-19. Frontline managers were found to have a critical role in incorporating human elements in turnaround management. The findings should encourage researchers to look more deeply into what can be done to ease the burden of radical change on frontline managers and employees. In addition, researchers could focus more on the role of human resources in turnaround management and other radical changes in the context of a crisis.

In particular, there is a need to develop research-based recommendations specifically oriented to the frontline and those who manage them. What resources and skills do they need to implement turnaround management practices? To what extent are these skills valuable outside the turnaround or change context? What are the main roles that the frontline perform, and how can they develop better relationships with employees on the one hand, and more senior managers on the other, while in the context of continually changing environments, such as COVID-19?

As this study used a theoretically selected sample-that is, people working in an organization that has undergone and is undergoing turnaround management- the issue of sampling bias could be a concern because the selected sample was not random and did not represent the entire population. For example, this research has focused on the perspectives of front-line managers. However, senior managers may have different perspectives on the topics that were explored in the present study. Future research should include an investigation of senior manager perspectives. Moreover, there may be recall bias, as during the interviews, the participants did not recognize the organization's learning over the years. Although the organization developed with each turnaround management event, the participants did not reflect on its progress.

To avoid sampling bias and to investigate beyond the convenience sampling approach, this study should be expanded upon and replicated in larger samples, and similar studies should be conducted on organizations in other sectors. It is also recommended to conduct a comparative analysis across countries, specifically, comparing the degree of restrictions and lockdowns within sectors in different countries. These studies, with larger samples, could also use qualitative interviews or case study methods. We suggest including a subsequent development of quantitative hypothesis testing for cross-sectional or longitudinal studies to confirm major findings.

The study's findings are limited by the possibility that an organization's stage of financial distress may influence the findings [8]. Additionally, this study focused on the planning and implementation stages of turnaround management. Other stages of turnaround management have not been investigated. Therefore, we suggest that future researchers should consider different stages of turnaround management and incorporate the organization's financial position as a contingent factor.

\section{Conclusions}

This qualitative study aimed to explore the challenges of turnaround management strategies of organizations operating within the aviation sector in Australia during the COVID-19 crisis and government restrictions, from the perspective of frontline managers. Learning about these challenges facing frontline management will help organizations that are planning to implement turnaround management strategies to overcome such issues and implement more effective change practices. The study analyzes 30 semi-structured interviews with frontline managers working for airline service providers in three different departments of a major airport in Australia. In conclusion, the findings 
suggest that frontline managers were challenged by inadequate human resources. Subsequently, this study addressed this issue by highlighting the importance of collective involvement in planning and decision-making, treating frontline managers as strategic partners by suggesting that a task force of frontline managers should be formed. Additionally, the findings highlighted a lack of communication during the turnaround management process. Therefore, this study emphasizes the critical role of clear, consistent, and open communication-perhaps even more so amid a crisis than in more routine changes, as it affects employees' attitudes to a greater extent in the turbulent and uncertain environment of COVID-19. It was recommended to create a joint communication plan between frontline and senior managers to address the challenge of the lack of communication. This study generated two theoretical contributions: it helps to gain a deeper understanding of frontline managers' challenges during the government restrictions of COVID-19 and emphasizes the important role of frontline managers while implementing turnaround management strategies. This should help managers and researchers to better incorporate human elements in turnaround management practices during COVID-19 government restrictions, which may reduce the problems caused by layoffs and negative psychological reactions among employees.

Author Contributions: P.-S.S. and A.C. designed and directed the study. B.B. worked on almost all the technical details. P.-S.S. and A.C. provided critical feedback and helped to shape the research. B.B. wrote the manuscript in consultation with P.-S.S. and A.C. All authors have read and agreed to the published version of the manuscript.

Funding: This research received no external funding.

Conflicts of Interest: The authors declare no conflict of interest.

\section{References}

1. Zhu, N.; Zhang, D.; Wang, W.; Li, X.; Yang, B.; Song, J.; Zhao, X.; Huang, B.; Shi, W.; Lu, R.; et al. A novel coronavirus from patients with pneumonia in China, 2019. N. Engl. J. Med. 2020, 382, 8. [CrossRef]

2. Del Rio-Chanona, R.M.; Mealy, P.; Pichler, A.; Lafond, F.; Farmer, D. Supply and demand shocks in the COVID-19 pandemic: An industry and occupation perspective. arXiv 2020, arXiv:2004.06759.

3. Baldwin, R.; Weder di Mauro, B. Introduction. In Economics in the Time of COVID-19; Baldwin, R., Weder di Mauro, B., Eds.; CEPR: London, UK, 2020.

4. Muellbauer, J. The Coronavirus Pandemic and US Consumption. VOX CERP Policy Portal 2020. Available online: https://voxeu.org/article/coronavirus-pandemic-and-us-consumption (accessed on 1 April 2020).

5. Voltes-Dorta, A.; Pagliari, R. The impact of recession on airports' cost efficiency. Transp. Policy 2012, 24, 211-222. [CrossRef]

6. ACI. ACI Advisory Bulletin. The Impact of COVID-19 on the Airport Business. 2020. Available online: https: //aci.aero/wp-content/uploads/2020/03/200401-COVID19-Economic-Impact-Bulletin-FINAL-1.pdf (accessed on 1 April 2020).

7. ICAO. Effects of Novel Coronavirus (Covid-19) on Civil Aviation: Economic Impact Analysis. 2020. Available online: https://www.icao.int/sustainability/Documents/COVID19/ICOA_Coronavirus_Econ_Impact.pdf (accessed on 15 April 2020).

8. Zeni, S.B.; Ameer, R. Turnaround prediction of distressed companies: Evidence from Malaysia. J. Financ. Report. Account. 2010, 8, 143-159.

9. Akdogan, A.; Cingoz, A. The effects of organizational downsizing and layoffs on organizational commitment: A field research. J. Am. Acad. Bus. 2009, 14, 337-344.

10. Pandit, N.R. Some recommendations for improved research on corporate turnaround. Management 2000, 3, 31-56.

11. Pillay, J. Corporate Turnaround as Knowledge Subversion: A Dialogic Perspective on Transformational Change. Ph.D. Thesis, Cranfield University, Bedford, UK, 2013.

12. McCalman, J.; Paton, R.; Siebert, S. Change Management: A Guide to Effective Implementation, 4th ed.; SAGE: Los Angeles, CA, USA, 2016.

13. Allen, T.; Freeman, D.; Russell, J.; Reizenstein, R.; Rentz, J. Survivor reactions to organisational downsizing: Does time ease the pain? J. Occup. Organ. Psychol. 2001, 74, 145-164. [CrossRef] 
14. Conway, E.; Monks, K. Change from below: The role of middle managers in mediating paradoxical change. Hum. Res. Manag. J. 2011, 21, 190-203. [CrossRef]

15. Hassard, J.; McCann, L.; Morris, J. Employment relations and managerial work: An international perspective. In Study Handbook on the Future of Work and Employment Relations; Townsend, K., Wilkinson, A., Eds.; Edward Elgar: Cheltenham, UK; Northampton, MA, USA, 2011; pp. 150-166. [CrossRef]

16. Fenton-O'Creevy, M. Employee involvement and the middle manager: Saboteur or scapegoat? Hum. Res. Manag. J. 2001, 11, 24-40. [CrossRef]

17. Barrett, D.J. Change communication: Using strategic employee communication to facilitate major change. Corp. Commun. 2002, 7, 219-231. [CrossRef]

18. Draft, R. Building Management Skills: An Action-First Approach; South Western-Cengage Learning: Mason, $\mathrm{OH}, \mathrm{USA}, 2014$.

19. Wei Tian, A.; Cordery, J.; Gamble, J. Returning the favor: Positive employee responses to supervisor and peer support for training transfer. Int. J. Train. Dev. 2016, 20, 1-16. [CrossRef]

20. Liou, D.; Smith, M. Financial distress and corporate turnaround: A review of the literature and agenda for study. Account. Account. Perform. 2007, 13, 74-114.

21. Schoenberg, R.; Collier, N.; Bowman, C. Strategies for business turnaround and recovery: A review and synthesis. Eur. Bus. Rev. 2013, 25, 243-262. [CrossRef]

22. GDA (Global Data Analysis). Coronavirus (COVID-19) Executive Briefing; Global Data: London, UK, 2020.

23. Williams, T.A.; Gruber, D.A.; Sutcliffe, K.M.; Shepherd, D.A.; Zhao, E.Y. Organizational to adversity: Fusing crisis management and resilience research streams. Acad. Manag. Ann. 2017, 11, 733-769. [CrossRef]

24. Lerbinger, O. The Crisis Manager: Facing Disasters, Conflicts, and Failures, 2nd ed.; Routledge: New York, NY, USA, 2012.

25. Herbane, B. Exploring crisis management in UK small-and-medium-sized enterprises. J. Conting. Crisis Manag. 2013, 21, 82-95. [CrossRef]

26. Alexander, P. Rebellion of the poor: South Africa's service delivery protests-A preliminary analysis. Rev. Afr. Political Econ. 2010, 37, 25-40. [CrossRef]

27. Powell, F.; Harding, A.; Thomas, J.; Mora, K. Rapid response research in Christchurch: Providing evidence for recovery decisions and for future theoretical research. Australas. J. Disaster Trauma Stud. 2011, 2, $26-34$.

28. French, W.; Bell, C.H., Jr.; Zawacki, R.A. Organization Development and Transformation: Managing Effective Change, 6th ed.; McGraw Hill/Irwin: New York, NY, USA, 2005.

29. Nystrom, P.; Starbuck, W. To avoid organizational crises, unlearn. Soc. Sci. Study Netw. 2015, 12, 53-65. [CrossRef]

30. Beeri, I. Turnaround management strategies in public systems: The impact on group-level organisational citizenship behavior. Int. Rev. Adm. Sci. 2012, 78, 158-179. [CrossRef]

31. Yandava, B. A capability-driven turnaround strategy for the current economic environment. J. Bus. Strateg. 2012, 29, 157.

32. Panicker, S. Successful turnarounds: The role of appropriate entrepreneurial strategies. J. Strat. Manag. 2015, 8, 21-40. [CrossRef]

33. Boyne, G.A.A. "3Rs" strategy for public service turnaround: Retrenchment, repositioning and reorganization. Public Money Manag. 2004, 24, 97-103. [CrossRef]

34. Stace, D.; Dunphy, D. Beyond the Boundaries: Leading and Re-Creating the Successful Enterprise, 2nd ed.; McGraw-Hill: Sydney, Australia, 2001.

35. Molinsky, A.; Margolis, J. The emotional tightrope of downsizing: Hidden challenges for leaders and their organizations. Organ. Dyn. 2006, 35, 145-159. [CrossRef]

36. Ryan, P.; Moroney, M.; Geoghegan, W.; Cunningham, J. A framework for a strategic reposition strategy: A case study of Bulmers Original Cider. Irish J. Manag. 2007, 28, 81-102.

37. Lawton, T.; Rajwani, T.; O'Kane, C. Strategic reorientation and business turnaround: The case of global legacy airlines. J. Strat. Manag. 2011, 4, 215-237. [CrossRef]

38. Barker, V.L.; Barr, P.S. Linking top manager attributions to strategic reorientation in declining firms attempting turnarounds. J. Bus. Study 2002, 55, 963-979. [CrossRef]

39. Budros, A. A conceptual framework for analyzing why organizations downsize. Organ. Sci. 1999, 10, 69-82. [CrossRef] 
40. Wilkinson, A. Downsizing, rightsizing or dumbsizing? Quality, human resources and the management of sustainability. Total Qual. Manag. Bus. Excell. 2005, 16, 1079-1088. [CrossRef]

41. Lowe, D.; Levitt, K.J.; Wilson, T. Solutions for retaining Generation Y employees in the workplace. Bus. Renaiss. 2008, 3, 43-57. [CrossRef]

42. Scherrer, P.S. Stages of the turnaround plan. Bus. Credit 2003, 105, 70-71.

43. Jacobs, R.W. Real Time Strategic Change: How to Involve an Entire Organization in Fast and Far-Reaching Change; Berrett-Koehler Publishers: San Francisco, CA, USA, 1994. [CrossRef]

44. Caldwell, A. Manager: Fear Was Common at Mint. Denver Post. Available online: https://www.denverpost. com/2005/09/15/manager-fear-was-common-at-mint/ (accessed on 15 September 2005).

45. Lee, B.A. Legal pitfalls of downsizing. Hum. Res. Manag. Rev. 1995, 5, 1-23. [CrossRef]

46. Harvey, N. Managing turnaround. Account. SA 2004, 2, 16-19.

47. Barker, V.L., III; Patterson, P., Jr.; Mueller, G. Organizational causes and strategic consequences of the extent of top management team replacement during turnaround attempts. J. Manag. Stud. 2001, 38, 235-270. [CrossRef]

48. Kirkman, B.L.; Jones, R.G.; Shapiro, D.L. Why do employees resist teams? Examining the "resistance barrier" to work team effectiveness. Int. J. Confl. Manag. 2000, 11, 74-92. [CrossRef]

49. Perry, L.T. Least-cost alternatives to layoffs in declining industries. Organ. Dyn. 1986, 14, 48-61. [CrossRef]

50. Slatter, S.S.P.; Lovett, D. Corporate Turnaround; Ser. Penguin Business: Penguin, Australia, 1999.

51. Staver, M. In Business. Available online: https://inbusinessphx.com/leadership-management/the-strengthof-no-blame-game-leadership\#.X5aiHO3hU2w (accessed on 5 May 2020).

52. Rosairo, R.H.; Kawamura, T.; Peiris, T.L. The coir industry in Sri Lanka: Reasons for its decline and possible business turnaround strategies. Agribusiness 2004, 20, 495-516. [CrossRef]

53. Elearn Limited. Change Management; Pergamon Flexible Learning: Oxford, UK, 2007.

54. Smith, R.; King, D.; Sidhu, R.; Skelsey, D. (Eds.) The Effective Change Manager's Handbook: Essential Guidance to the Change Management Body of Knowledge; Kogan Page: London, UK, 2014.

55. Brenner, S. Balance stakeholder interests. Bus. Soc. 1998, 37, 73.

56. Anderson, D.; Ackerman-Anderson, L. Beyond Change Management: How to Achieve Breakthrough Results through Conscious Change Leadership, 2nd ed.; Pfeiffer: San Francisco, CA, USA, 2010.

57. Tomlinson, E.C.; Dineen, B.R.; Lewicki, R.J. The road to reconciliation: Antecedents of victim willingness to reconcile following a broken promise. J. Manag. 2004, 30, 165-187. [CrossRef]

58. Cropanzano, R.; Bowen, D.E.; Gilliland, S.W. The management of organizational justice. Acad. Manag. Perspect. 2007, 21, 34-48. [CrossRef]

59. Kitchen, P.J.; Daly, F. Internal communication during change management. Corp. Commun. Intern. J. 2002, 7, 46-53. [CrossRef]

60. Hutchinson, S.; Purcell, J. Managing ward managers for roles in HRM management in the NHS: Overworked and under-resourced. Hum. Res. Manag. J. 2010, 20, 357-374. [CrossRef]

61. Townsend, K.; Loudoun, R.; Markwell, K. The role of line managers in creating and maintaining healthy work environments on project construction sites. Constr. Manag. Econ. 2016, 34, 611-621. [CrossRef]

62. Hales, C. Rooted in supervision, branching into management: Continuity and change in the role of first line manager. J. Manag. Stud. 2005, 42, 471-506. [CrossRef]

63. Martins, L. The nature of the changing role of first-tier managers: A long-cycle approach. J. Organ. Chang. Manag. 2009, 22, 92-123. [CrossRef]

64. Hutchinson, S.; Purcell, J. The Role of Line Managers in Reward, and Training, Learning and Development; CIPD: London, UK, 2007.

65. Whittaker, S.; Marchington, M. Devolving HR responsibility to the line: Threat, opportunity or partnership? Empl. Relat. 2003, 36, 245-261. [CrossRef]

66. Perry, E.L.; Kulik, C.T. The devolution of HR to the line: Implication of perceptions of people management effectiveness. Intern. J. Hum. Res. Manag. 2008, 19, 262-273. [CrossRef]

67. Creswell, J. Qualitative Inquiry \& Study Design: Choosing among Five Approaches, 3rd ed.; SAGE Publications: Los Angeles, CA, USA, 2013.

68. Neuman, W. Social Study Methods: Qualitative and Quantitative Approaches, 7th ed.; Allyn \& Bacon: Boston, MA, USA, 2011.

69. Yin, R. Qualitative Study from Start to Finish; Guilford Publications: New York, NY, USA, 2010. 
70. Silverman, D. Qualitative Study: Issues of Theory, Method, and Practice, 3rd ed.; Sage: Los Angeles, CA, USA, 2011.

71. Creswell, J.; Creswell, J. Study Design: Qualitative, Quantitative, and Mixed Methods Approaches, 5th ed.; SAGE Publications: Thousand Oaks, CA, USA, 2018. [CrossRef]

72. Lim, P.S. Organisational Change and Impact on the Individual. Ph.D. Thesis, George Washington University, Washington, DC, USA, 2006. Unpublished.

73. Braun, V.; Clarke, V. Using thematic analysis psychology. Qual. Study Psychol. 2006, 3, 77-101. [CrossRef]

74. Saldaña, J. The Coding Manual for Qualitative Researchers; Sage: Thousand Oaks, CA, USA, 2009.

75. Elg, U.; Ghauri, P.N. Systematic data analysis for multinational case study research. SAGE Res. Methods Cases 2019. [CrossRef]

76. Saldaña, J. The Coding Manual for Qualitative Researchers, 2nd ed.; Sage: London, UK, 2013.

77. Ritchie, J.; Lewis, J. Qualitative Study Practice; SAGE Publications Inc.: Thousand Oaks, CA, USA, 2006.

78. Pratt, M. From the editors: For the lack of a boilerplate: Tips on writing up (and reviewing) qualitative study. Acad. Manag. J. 2009, 52, 856-886. [CrossRef]

79. Pratt, M. Fitting oval pegs into round holes: Tensions in evaluating and publishing qualitative study in top-tier North American journals. Organ. Study Methods 2008, 11, 481-509. [CrossRef]

80. Armstrong-Stassen, M. Coping with downsizing: A comparison of executive level and middle managers. Int. J. Stress Manag. 2005, 12, 117-141. [CrossRef]

81. Fossum, L. Understanding Organisational Change: Converting Theory to Practice; Crisp Publications: Los Altos, CA, USA, 1989.

82. Herholdt, J. Managing Change in Organisations; Knowres Publishing: Randburg, South Africa, 2012.

83. King, N. Innovation and Change in Organisations; Routledge: London, UK, 1995.

84. Palmer, B. Making Change Work: Practical Tools for Overcoming Human Resistance to Change; ASQ Quality Press: Milwaukee, WI, USA, 2003.

85. Jacobs, D.; González, J.; Sheridan, G. Shockproof: How to Hardwire Your Business for Lasting Success; John Wiley \& Sons: Hoboken, NJ, USA, 2011.

86. Townsend, K.; Russell, B. Investigating the nuances of change in front-line managers' work. Lab. Ind. 2013, 23, 168-181. [CrossRef]

87. Larsen, H.H.; Brewster, C. Line management responsibility of HRM: What is happening in Europe? Empl. Relat. 2003, 25, 228-244. [CrossRef]

88. Renwick, D. Line Managers. In Contemporary Human Resource Management, 2nd ed.; Redman, T., Wilkinson, A., Eds.; FT/Prentice Hall: Harlow, UK, 2006.

89. Lohrke, F.T.; Bedeian, A.G.; Palmer, T.B. The role of top management teams in formulating and implementing turnaround strategies: A review and study agenda. Int. J. Manag. Rev. 2004, 5-6, 63-90. [CrossRef]

90. Lewis, L. Organisational Change: Creating Change through Strategic Communication; Wiley-Blackwell: Chichester, UK, 2001.

91. Edmonds, S. The Culture Engine: A Framework for Driving Results, Inspiring Your Employees, and Transforming Your Workplace; Wiley: Hoboken, NJ, USA, 2014.

92. Fitz-Enz, J. The New HR Analytics: Predicting the Economic Value of Your Company's Human Capital Investments; AMACOM: New York, NY, USA, 2010.

93. Heymann, J. Profit at the Bottom of the Ladder: Creating Value by Investing in Your Workforce; Harvard Business Press: Boston, MA, USA, 2010.

94. Balmer, J.M.T.; Invernizzi, E.; Romenti, S.; Fumagalli, M. Identity, communication and change management in ferrari. Corp. Commun. Int. J. 2012, 17, 483-497. [CrossRef]

95. McConville, T.; Holden, L. The filling in the sandwich: Managers in the health sector. Pers. Rev. 1999, 28, 406-424. [CrossRef]

96. Grey, J. Executive Advantage: Resilient Leadership for 21st-Century Organisations; Kogan Page: London, UK, 2013.

97. Ha, H. Change Management for Sustainability, 1st ed.; Business Expert Press: New York, NY, USA, 2014.

98. Townsend, K.; Wilkinson, A.; Burgess, J. Filling the gaps: Patterns of formal and informal participation. Econ. Ind. Democr. 2013, 34, 337-354. [CrossRef]

99. Kerr, S.; Hill, K.D.; Broedling, L. The first-line supervisor: Phasing out or here to stay? Acad. Manag. Rev. 1986, 11, 103-117. [CrossRef]

100. Thurley, K.; Wirdenius, H. Supervision: A Re-Appraisal; Heinemann: London, UK, 1973. 
101. Child, J.; Partridge, B. The Lost Managers: Supervisors in Industry and Society; Cambridge University Press: Cambridge, UK, 1982.

102. Birolini, S.; Malighetti, P.; Redondi, R.; Deforza, P. Access mode choice to low-cost airports: Evaluation of new direct rail services at milan-bergamo airport. Trans. Policy 2019, 73, 113-124. [CrossRef]

Publisher's Note: MDPI stays neutral with regard to jurisdictional claims in published maps and institutional affiliations.

(C) 2020 by the authors. Licensee MDPI, Basel, Switzerland. This article is an open access article distributed under the terms and conditions of the Creative Commons Attribution (CC BY) license (http://creativecommons.org/licenses/by/4.0/). 